\title{
TARDOKI-YANI RANGE (NORTH SIKHOTE-ALIN, PACIFIC RUSSIA) - THE LARGEST SOUTHERN REFUGIUM OF ARCTIC-ALPINE LIVERWORT FLORA IN EAST ASIA
}

\section{ХРЕБЕТ ТАРДОКИ-ЯНИ (СЕВЕРНЫЙ СИХОТЭ-АЛИНЬ, ТИХООКЕАНСКАЯ РОССИЯ) - КРУПНЕЙШИЙ ЮЖНЫЙ РЕФУГИУМ АРКТО-АЛЬПИЙСКОЙ ФЛОРЫ ПЕЧЕНОЧНИКОВ В ВОСТОЧНОЙ АЗИИ}

\author{
VADIM A. BAKALIN ${ }^{1,2}$ \\ ВАДИМ А. БАКАЛИН ${ }^{1,2}$
}

\begin{abstract}
The hepatic flora of Tardoki-Yani Mts., a subordinate range in the northern part of Sikhote-Alin mountain system, was studied and analyzed. In total, 106 species were found, 24 of them are new for Sikhote-Alin. The flora is a mixture of temperate East Asian and circumpolar arctic-alpine taxa, the fact corresponding the geographic position of Tardoki-Yani Mts. at the boundary between East-Asian and Circumboreal floristic provinces, as well as the wide range of elevations, from 500 to $2090 \mathrm{~m}$, the latter being the highest point of Sikhote-Alin. Many arctic-alpine taxa occur in Tardoki-Yani in considerable isolation from the nearest localities in northern Asia and are the southernmost in the world. The latter, as well as wide distribution of late glacial landscapes in the studied area allow us to consider Tardoki-Yani as the largest southern refugium of arctic-alpine hepatic flora in East Asia.
\end{abstract}

Резюме

Флора печеночников Тардоки-Яни - хребта в системе северного Сихотэ-Алиня - изучена и проанализирована. Выявлено 106 видов, 24 из которых являются новинками для Сихотэ-Алиня. В изученной флоре представлены неморальные восточноазиатские и циркумполярные арктоальпийские таксоны, что является следствием положения района на стыке Циркумбореальной и Восточноазиатской флористических областей, а также значительного диапазона высот (наивысшая точка Сихотэ-Алиня расположена в пределах изученного хребта). Большинство аркто-альпийских таксонов встречаются на Тардоки-Яни в значительном отрыве от ближайших местонахождений в Северной Азии и являются наиболее южными в мире. Последнее, а также широкое распространение ледниковых форм рельефа позволяет рассматривать Тардоки-Яни в качестве крупнейшего южного рефугиума арктоальпийской флоры в Восточной Азии.

KEYWORDS: liverworts, Hepaticae, East Asia, refugium, phytogeography, Sikhote-Alin Range, Russian Far East

\section{INTRODUCTION}

Vascular plant flora of Sikhote-Alin highlands attracted the great attention of botanists for a long time (cf. Vyshin, 1990; Prokopenko, 2011, etc.). Conversely, the hepatic flora of the latter had much less attention. There is the only paper of Gambaryan (1984), entitled "On the hepatic flora of highlands and spurs of South SikhoteAlin". However, the approach to the highlands vegetation in a broad sense, including highland spruce forests resulted in inclusion to the "highland communities" warm temperate species, e.g., Metacalypogeia cordifolia and Bazzania ovifolia. If to restrict highlands by alpine forestless areas in a way universally accepted by the vascular plant botanists, many species from Gambaryan's list should be omitted, so among the hepatics growing above timberline only three species would remain: Sphenolobus saxicola, Macrodiplophyllum microdontum and Marsupella tubulosa.

To fill the gap I undertook a number of trips in the last couple of years to study highlands of the southern Sikhote-Alin Range. However, elevations of peaks in the area are from 1600 to $1800 \mathrm{~m}$, which is not enough to form 'true' alpine tundra in $43-45^{\circ}$ of northern latitude in East Asia, although many rock fields (gravelly barrens) are formed there due to severe wind regime and local permafrost distribution. The study of southern Sikhote-Alin highlands revealed several rare and new taxa for the mountain system (Tetralophozia setiformis, Sphenolobopsis pearsonii, Scapania sphaerifera, etc.), but findings of arctic-alpine species remained very few. This

1 - Botanical Garden-Institute FEB RAS, Makovskogo Street, 142, Vladivostok, 690024, Russia - Ботанический сад-институт ДВО РАН, ул. Маковского, 142, Владивосток, 690024.

2 - Institute of Biology and Soil Science FEB RAS, Stoletiya Vladivostoka Avenue, 159, Vladivostok, 690022, Russia, Биологопочвенный институт ДВО РАН, пр. Столетия Владивостока, 159, Владивосток, 690022; e-mail: vabakalin@gmail.com 
inclined us to conclude that the highland liverwort flora of Sikhote-Alin Range is almost completely devoid of arctic-alpine hepatics. However, in 2012, Dr. Vyacheslav Barkalov (VLA) explored vascular plants of the Tardoki-Yani mountain range in the northern Sikhote-Alin and also collected a set of hepatics at my request, a small one, as his work in the alpine belt near the mountain top lasted only two hours. Even the first look at this obviously fragmentary liverwort collection showed that the Tardoki-Yani alpine belt stands quite apart from all previously studied areas of the Sikhote-Alin Range. For example, in the first five specimens I found Cryptocolea imbricata and Frullania subarctica, species strongly unexpected in so southern region. Taking into account these facts, in the autumn of 2013, I undertook a special trip to the Tardoki-Yani Range, with 10 days for bryophyte exploration.

\section{STUDY AREA}

Sikhote-Alin is the large, nearly meridionally oriented mountain system that stretches from $43^{\circ} \mathrm{N}$ to $51^{\circ} \mathrm{N}$ and is divided into three main parts: southern, middle and northern. It also links the discontinuous set of mountain systems on the eastern edge of the Asian continent, particularly uniting mountains of North-East China and Korean Peninsula with large ranges of East Siberia. North Sikhote-Alin is a system of meridionally oriented mountain ranges with average peaks of 1300-1400 m elev., with only few mountains exceeding $1700 \mathrm{~m}$ and only two (Tardoki-Yani Mt. and Ko Mt.) higher than $2000 \mathrm{~m}$ (Shlotgauer et al., 2001). Tardoki-Yani Mt. is the peak of the subordinate range of the same name within SikhoteAlin system and it is the highest point of Sikhote-Alin (2090 m). Northern slopes of the range commonly bear mountain cirques and moraine trails - a result of late Pleistocene glaciation in the area.

The main 'macro-ecotypes' in the studied area are (modified after Shlotgauer et al., 2001, only visited types listed): 1) flattened tops and saddles constructed by granitoids of early Cretaceous time with gravelly barrens, dwarf shrub-lichen, dwarf shrub-grass and polygonal mountain tundras; 2) gentle slopes of gravelly barrens and talus, free of continuous vegetation cover; 3 ) moderately steep slopes with ridges and outliers, covered by Pinus pumila (Pall.) Regel and Rhododendron aureum Franch. thickets; 4) mountain lake beds, cirques; 5) mountain terraces on moraines, covered by thickets of Betula lanata (Regel) V.N. Vassil. (=B. ermanii var. lanata) and Weigela middendorffiana $\mathrm{C}$. Koch; 6) alluvial cones in lower course of rivers, covered by coniferous forests; 7) valleys covered by mixed forests (Chosenia, Populus, Betula, conifers) on alluvial soils.

Climate in Tardoki-Yani Range is of monsoon type with wet summer and dry and cold winter. The average annual precipitation at low elevations is about $1000 \mathrm{~mm}$ per year (with summer maximum), while in high mountaines the summer precipitation noticeably increases due to interception of wet air masses going from Pacific Ocean. However, during winter, cold and dry air masses from Siberia dominate at elevations up to $4000 \mathrm{~m}$ and wet air masses cannot be stopped by Sikhote-Alin (Vyshin, 1990).

North Sikhote-Alin houses following vegetation belts (down from the tops): mountain tundra, subalpine shrubs, birch crooked forests, fir-spruce forests and larch forests of lowland (pure larch forests are absent in studied area) (Vyshin, 1990). The delimitation of those belts is rather conventional due to various and deep penetrations of one belt to another. Forests at low elevations (in studied area from 500 to $700 \mathrm{~m}$ ) are dominated by Picea ajanensis Fisch. ex Carrière and Abies nephrolepis (Trautv. ex Maxim.) Maxim. with common admixture of Populus, Chosenia, and Salix in deep valleys. These forests commonly have a lot of shrubs (Rosa, Eleutherococcus, Rhododendron mucronulatum Turcz., etc.) in their understory. This elevation diapason houses the most thermophilic elements of the bryophyte flora (Cololejuenea macounii, Lejeunea japonica, etc.). Above $700 \mathrm{~m}$ the canopy becomes more open and the average height of trees becomes lesser, although dominant composition of the vegetation does not undergo remarkable alterations, with the exception of wide penetration of Betula lanata.

Above $800 \mathrm{~m}$ a.s.1., the proportion of Betula in communities noticeably increases (although it does not exceed $20 \%$ of coverage). Above $900 \mathrm{~m}$, vegetation is represented by a mosaic combination of communities that depends (as far as I could see) upon relief features. Gentle slopes and valleys are covered with spruce forest (rarely with slight admixture of Larix gmelinii (Rupr.) Kuzen.), steep slopes and ridge lines of small spurs have Pinus pumila and Weigela middendorffiana thickets and flattened surfaces near the tops of small spurs are occupied by mountain tundras. More or less sizable and pure formation of Betula lanata was observed only once, in the flat bed of mountain cirque at an elevation $1500 \mathrm{~m}$. Described mosaic varied in the proportions of the types of vegetation from dominance of forests at $900 \mathrm{~m}$ to ultimate dominance of mountain tundras above $1600 \mathrm{~m}$. Pinus pumila is going much higher than other shrubs and locally forms dense communities in watershed ridges or over large-block barrens on steep slopes up to $1700 \mathrm{~m}$, and occurs as isolated and poorly developed plants up to $1800-1850 \mathrm{~m}$. Another 'tree' in that elevation is Larix, represented here as dwarf "sprawled shrub" of 0.4-0.6 m height (Vyshin, 1990: 24).

Mountain tundra belt in Tardoki-Yani is rather unique among Sikhote-Alin Mountains and occupies a relatively large area (ca. 6 square $\mathrm{km}$ ). The following habitat types may be found there: 1) wet mossy Sphagnum-dominated tundras in saddles, 2) moderately moistened dwarf shrub-moss tundras on gentle slopes, 3 ) dry moss-lichen tundras on flat surfaces near ridge-lines and on slopes, 4) cliffy areas on steep slopes, 5) dry cliffs near ridge- 
line, 6) gravelly barrens and cliffs on steep slopes, 7) flattened surfaces and gentle slopes near the highest points of the range. The major types of Tardoki-Yani landscapes are illustrated in Figs. 1-16.

\section{MATERIAL AND METHODS}

Field studies were carried out within 10 days at the end of August 2013 from low elevations, $540 \mathrm{~m}$, on southern slope of Tardoki-Yani Mt. Range, to variously faced alpine-subalpine belt of the range ( $48^{\circ} 48-53^{\prime} \mathrm{N}, 138^{\circ} 01-07^{\prime}$ E), including the peak (2090 a.s.1.). In total, 322 specimens (and many duplicates) of liverworts were collected. The exploration repeatedly covered all present in the study area types of habitats in different elevations. Each specimen was annotated with data on geographic position (coordinates), elevation, habitat type, community type, exposure and illuminance (open to full shade). All specimens were kept in fresh condition and then were studied for oil-bodies characteristic immediately after returning to the laboratory (VBGI).

\section{SPECIES LIST}

Nomenclature mostly follows that published in Bakalin (2010). Each taxon is annotated by: 1) presence of generative organs or vegetative propagules, with the abbreviations: ant. - antheridia, arch. - archegonia, per. perianths, spor. - sporogonia, gemm. - gemmae; 2) altitudinal range, in meters (the hyphen between two numerals means that there is at least one collection between extremes); 3) description of habitats; 4) list of accompanying liverwort species, if available (for common taxa with many accompanying taxa only most characteristic ones are cited).

Anastrophyllum michauxii (F. Weber) H. Buch - per., ant. 500-800 m - Mesic to moist (rarely wet) decorticated decaying wood in partial shade, in coniferous to mixed forest developed in narrow valleys of streams and flood plain. In pure mats or with Blepharostoma trichophyllum var. trichophyllum, Cephalozia spp., Lepidozia reptans, Lophozia silvicola, Mylia verrucosa, Nowellia curvifolia, Riccardia palmata, Scapania apiculata.

Aneura pinguis (L.) Dumort. - ant. - 870-2010 m - Decaying decorticated wood in mesic condition at low elevations, in coniferous forests; mesic to wet cliff crevices in higher altitudes in alpine belt. In pure mats or (in alpine belt) with Anthelia juratzkana, Blepharostoma trichophyllum var. brevirete, Calycularia laxa, Frullania subarctica, Plagiochila porelloides, Radula prolifera, Tritomaria exsecta, Scapania crassiretis.

Anthelia juratzkana (Limpr.) Trev. - per., ant. - 1680-2010 m - Mesic to moist cliff crevices, bare soil in solifluction spots, in alpine belt on lowered tundras among subalpine shrubs. In pure mats or with Aneura pinguis, Blepharostoma trichophyllum var. brevirete, Lophozia lantratoviae, Marsupella boeckii, M. commutata, Plectocolea obscura, Solenostoma rossicum.

Apometzgeria pubescens (Schrank) Kuwah. - ant., arch. - 540$1880 \mathrm{~m}$ - Abies trunks and branches in partial shade in coniferous forest belt, rarely mesic decaying decorticated wood in forest belt and cliff crevices in subalpine shrubs belt. In pure mats or with Cololejeunea macounii, Frullania davurica, Lejeunea japonica, Lophocolea heterophylla, Mylia verrucosa, Nowellia curvifolia, Plagiochila porelloides, Radula complanata, Tritomaria quinquedentata.

Apotreubia nana (S. Hatt. et H. Inoue) S. Hatt. et Mizut. gemm. - 1940-2090 m - Large moist cliff crevices and flat ledges on N-facing slopes, mostly on hygrophytic mosses (esp. Sphagnum), in alpine belt. In pure mats or with Calycularia laxa, Herbertus dicranus, Macrodiplophyllum microdontum, Mylia taylorii, Plagiochila arctica, Scapania crassiretis, Schistochilopsis opacifolia, Tritomaria quinquedentata.

Barbilophozia barbata (Schmid. ex Schreb.) Loeske - 610$1930 \mathrm{~m}$ - Mesic to moist decaying wood, cliffs in open places in forest belt, over mesic moss patches in dwarf shrublichen tundra, in alpine belt. In pure mats or with Ptilidium pulcherrimum, Scapania apiculata, Tritomaria exsecta.

Bazzania ovifolia (Steph.) Hatt. - 610-770 m - Moist to mesic decaying wood, shaded mesic to moist cliffs, in coniferous forest belt. In pure mats or with Lepidozia reptans, Mylia verrucosa, Sphenolobus minutus.

B. tricrenata (Wahlenb.) Lindb. - 1820-2050 m - Mesic to moist cliff crevices in alpine belt. In pure mats or with Frullania subarctica, Herbertus dicranus, Radula prolifera, Scapania crassiretis, Tritomaria quinquedentata.

B. trilobata (L.) S. Gray - 540-770 m - Soil rich in humus on steep slope, mesic to moist decaying wood in coniferous forest belt. In pure mats.

Blepharostoma trichophyllum (L.) Dumort. var. brevirete Bryhn et Kaal. - 1940-2090 m - Mesic cliffs in open to partly shaded places, over Sphagnum on flat cliff ledges, in alpine belt. Rarely in pure mats; commonly with Aneura pinguis, Frullania subarctica, Lophozia lantratoviae, Plagiochila porelloides, Radula prolifera, Tritomaria quinquedentata.

B. trichophyllum (L.) Dumort. var. trichophyllum - per. - 610$2010 \mathrm{~m}$ - Moist to mesic decaying decorticated wood in coniferous forest belt, cliff crevices and caves in alpine belt. In pure mats or with Calycularia laxa, Diplophyllum taxifolium, Macrodiplophyllum plicatum, Peltolepis quadrata, Plagiochila porelloides, Sauteria alpina, Tritomaria quinquedentata, etc. on cliffs or with Anastrophyllum michauxii, Cephalozia leucantha, C. lunulifolia, Crossocalyx hellerianus, Geocalyx graveolens, Lepidozia reptans, Mylia verrucosa, Nowellia curvifolia, Riccardia palmata, etc. on decaying wood.

Calycularia laxa Lindb. et Arnell - ant. - 870-2090 m - Cliff crevices and caves between stones in gravelly barrens, over mosses (mostly Sphagnum) on flat cliff ledges, from coniferous forest to alpine belt. In pure mats or with Apotreubia nana (only higher altitude), Blepharostoma trichophyllum var. trichophyllum, Calypogeia integristipula, Diplophyllum taxifolium, Macrodiplophyllum plicatum, Marsupella tubulosa, Tritomaria exsecta, T. quinquedentata, etc.

Calypogeia integristipula Steph. - gemm. - 540-2090 m Mesic to moist decaying decorticated wood in forest belt, crevices in gravelly barrens in alpine belt, in shaded places. In pure mats or with Calycularia laxa, Cephalozia lunulifolia, Mylia verrucosa, Schistochilopsis cornuta, Tritomaria exsecta.

C. sphagnicola (H.Arnell et J.Perss.) Warnst. \& Loeske - 1940$2010 \mathrm{~m}$ - Mesic to moist cliff crevices in open places in alpine belt. In pure mats or with Lophozia savicziae.

C. suecica (Arnell et J. Perss.) Mull. Frib. - gemm. - $617-$ Moist decaying wood in partly shaded places in conifer- 
ous forest belt. - With Geocalyx graveolens, Mylia verrucosa, Scapania apiculata, Nowellia curvifolia, Riccardia palmata.

Cephalozia bicuspidata (L.) Dumort. - per., ant. - 540-2090 $\mathrm{m}$ - Mesic to moist decaying wood in partly shaded sites in coniferous forest belt; crevices in cliffs and gravelly barrens, flat cliff ledges with hygrophytic moss cover, humus along streams in subalpine and alpine belts. Rarely in pure mats, more commonly with epixylous taxa on decaying wood (Blepharostoma trichophyllum var. trichophyllum, Cephalozia leucantha, Lepidozia reptans, Lophocolea heterophylla, Mylia verrucosa, etc.) or on mineral substrata with Nardia insecta, Plectocolea obscura, Scapania parvifolia, Schistochilopsis opacifolia, Solenostoma rossicum, Sphenolobus minutus, etc.

C. catenulata (Huebener) Lindb. - per. - 540-770 m - Moist to wet decaying wood in coniferous forest belt. With various epixylous taxa including Anastrophyllum michauxii, Blepharostoma trichophyllum var. trichophyllum, Geocalyx cf. graveolens, Lepidozia reptans, Lophozia silvicola, Mylia verrucosa, Nowellia curvifolia, Riccardia palmata, Schistochilopsis cornuta, Tritomaria exsecta, etc.

C. leucantha Spruce - per., ant. - 540-770 m - Mesic to moist decorticated decaying wood in coniferous forest belt. In pure mats or with Anastrophyllum michauxii, Blepharostoma trichophyllum var. trichophyllum, Cephalozia bicuspidata, Geocalyx cf. graveolens, Mylia verrucosa, Nowellia curvifolia, Scapania apiculata, Tritomaria exsecta.

C. otaruensis Steph. - per. $-870 \mathrm{~m}-$ Decaying decorticated wood in mesic conditions in upper part of coniferous forest belt. In pure mats (only one collection).

C. pleniceps (Aust.) Lindb. - per., ant. - $2090 \mathrm{~m}$ - Cliff crevice in partial shade in alpine belt. With Cephalozia bicuspidata, Radula prolifera, Scapania parvifolia, Sphenolobus minutus (only one collection).

Cephaloziella hampeana (Nees) Schiffn. - gemm. - 2010 m Cliff crevice in alpine belt. With Scapania crassiretis (only one collection).

C. rubella (Nees) Warnst. s. str. - ant., arch., gemm. $-870 \mathrm{~m}-$ Decaying decorticated wood in mesic condition in coniferous forest belt. In pure mat (only one collection).

Cololejeunea macounii (Spruce in Underw.) A. Evans - per., ant. $-540-770 \mathrm{~m}$ - Abies trunks and thin branches in lower part of coniferous forest belt. In pure mats or with Apometzgeria pubescens, Lejeunea japonica.

Crossocalyx hellerianus (Nees in Lindenb.) Meyl. - gemm. $765 \mathrm{~m}$ - Mesic decaying decorticated wood in coniferous forest belt. With Anastrophyllum michauxii, Blepharostoma trichophyllum var. trichophyllum, Lophocolea heterophylla, Mylia verrucosa, Nowellia curvifolia, Scapania apiculata (only one collection).

Cryptocolea imbricata R.M. Schust. - arch. - 1940-2010 m Moist cliff crevices in open places on N-facing slopes. In pure mats or with Scapania cf. crassiretis, Tritomaria quinquedentata.

Diplophyllum albicans (L.) Dumort. - gemm. - 870-2090 m Crevices in cliffs and gravelly barrens in upper part of coniferous forest belt to alpine belt. In pure mats or with Calycularia laxa, Gymnomitrion concinnatum, Marsupella commutata, M. tubulosa, Lophozia ventricosa var. longiflora, Scapania crassiretis, Tetralophozia setiformis, Tritomaria quinquedentata.
D. obtusatum (R.M. Schust.) R.M. Schust. - per., ant. - 610$770 \mathrm{~m}-$ Mesic to moist cliffs near streams in part shade in coniferous forest belt. In pure mats or with Metacalypogeia cordifolia, Marsupella tubulosa, Scapania crassiretis, Solenostoma pseudopyriflorum.

D. taxifolium (Wahlenb.) Dumort. - per. - 610-2010 m - Mesic to moist cliff crevices and caves and crevices in gravelly barrens, from partly shaded to open places, from coniferous forest belt to alpine belt. In pure mats or with taxa of various flora elements: Blepharostoma trichophyllum var. trichophyllum, Calycularia laxa, Gymnomitrion concinnatum, Lophozia sudetica, Macrodiplophyllum plicatum, Metacalypogeia cordifolia, Peltolepis quadrata, Solenostoma pseudopyriflorum, Tritomaria quinquedentata, etc.

Frullania bolanderi Aust. - ant. - $540 \mathrm{~m}$ - Mesic decaying wood in partly shaded places, in lower level of coniferous forest belt. In pure mats (only one collection).

F. davurica Hampe - 540-870, $1880 \mathrm{~m}$ - Tree trunks in coniferous forest belt or mesic cliff crevices in subalpine belt. In pure mats or with Apometzgeria pubescens and Frullania cf. koponenii in forest belt or with Lejeunea alaskana and Tritomaria quinquedentata in subalpine belt.

F. koponenii S. Hatt. - per. - 540-620 m - Abies trunks and branches in partial shade in coniferous forest belt. In pure mats or with Apometzgeria pubescens, Frullania davurica, Metzgeria temperata.

F. subarctica Vilnet, Borovich. et Bakalin - 1940-2010 m Mesic to moist cliffs in alpine belt. In pure mats or with Aneura pinguis, Bazzania tricrenata, Blepharostoma trichophyllum var. brevirete, B. trichophyllum var. trichophyllum, Calycularia laxa, Diplophyllum taxifolium, Herbertus dicranus, Macrodiplophyllum plicatum, Radula prolifera, Scapania crassiretis, Sphenolobus minutus, S. saxicola, Tritomaria exsecta, $T$. quinquedentata.

Geocalyx cf. graveolens (Schrad.) Nees - per. - 540-620 m Moist to wet decaying wood and soil rich in humus on steep slopes, in coniferous forest belt. In pure mats or with Anastrophyllum michauxii, Blepharostoma trichophyllum var. trichophyllum, Calypogeia suecica, Cephalozia bicuspidata, C. catenulata, C. leucantha, Lepidozia reptans, Lophozia silvicola, Mylia verrucosa, Nowellia curvifolia, Riccardia palmata, Scapania apiculata, Tritomaria exsecta.

Gymnocolea inflata (Huds.) Dumort. - per. - 1820-1930 m Wet crevices in gravelly barrens and wet mossy tundra, in alpine belt. In pure mats.

Gymnomitrion concinnatum (Lightf.) Corda - 1850-2090 m Mesic to moist crevices in cliffs and gravelly barrens in alpine belt. In pure mats or with Diplophyllum albicans, Marsupella tubulosa, Tetralophozia setiformis, Tritomaria quinquedentata.

G. corallioides Nees - arch., spor. juv. - $2010 \mathrm{~m}$ - Crevices in cliffs in alpine belt. In pure mats or with Marsupella alpina.

Herbertus dicranus (Taylor) Trevis - 610-2090 m - Vertical cliffs, cliff crevices, flat cliff ledges in mesic open to partly shaded places, mostly in alpine belt, rarely descends to coniferous forest belt. In pure mats or with Apotreubia nana, Blepharostoma trichophyllum var. trichophyllum, Calycularia laxa, Frullania subarctica, Lophozia sudetica, Macrodiplophyllum plicatum, M. microdontum, Marsupella alpina, M. tubulosa, Radula prolifera, Scapania crassiretis, Tritomaria quinquedentata, etc. 
Jungermannia exsertifolia Steph. - per. - $615 \mathrm{~m}$ - Wet boulder near stream in coniferous forest belt. In pure mats (one collection).

J. pumila With. - per., ant. - $1940 \mathrm{~m}$ - Moist cliff crevice in open place, in alpine belt. In pure mats.

Leiocolea heterocolpos (Thed. ex Hartm.) Buch - gemm. $1940 \mathrm{~m}$ - Moist cliff crevice in open place, in alpine belt. In pure mats (one collection).

Lejeunea alaskana (R.M. Schust. et Steere) H. Inoue et Steere - $1880 \mathrm{~m}-$ Mesic cliff crevices in open places, in alpine belt. In pure mats.

L. japonica Mitt. - per., ant. - 610-770 m - Picea and Abies trunks and thin branches, in partly shaded places, in coniferous forest belt. In pure mats or with Apometzgeria pubescens, Cololejeunea macounii.

Lepidozia reptans (L.) Dumort. - 540-870 m - Mesic to moist decaying decorticated wood in coniferous forest belt. In pure mats or with various epixylous taxa: Anastrophyllum michauxii, Bazzania ovifolia, Blepharostoma trichophyllum var. trichophyllum, Cephalozia catenulata, Geocalyx cf. graveolens, Lophocolea heterophylla, Mylia verrucosa, Nowellia curvifolia, Riccardia palmata, Scapania apiculata, etc. or (rarer) with eurytopic Bazzania ovifolia and Cephalozia bicuspidata.

Liochlaena subulata (Evans) Schljak. - gemm. - 615 m - Wet boulder near stream in coniferous forest belt. With Scapania crassiretis (one collection).

Lophocolea heterophylla (Schrad.) Dumort. - per., ant. - 540$770 \mathrm{~m}$ - Mesic to moist decaying wood in coniferous forest belt. - In pure mats or with Anastrophyllum michauxii, Apometzgeria pubescens, Blepharostoma trichophyllum var. trichophyllum, Cephalozia bicuspidata, Lepidozia reptans, Mylia verrucosa, Scapania apiculata, etc.

L. itoana H. Inoue - arch. - $1880 \mathrm{~m}$ - Partly shaded (under Calamagrostis canopy) sandy soil on steep slope in crooked forest belt. In pure mat (one collection).

L. minor Nees - gemm. - $540 \mathrm{~m}$ - Mesic decaying wood in coniferous forest belt. In pure mat (one collection).

Lophozia lantratoviae Bakalin - gemm. - 760-1940 m - Moist cliff crevices in alpine belt and wet stones along streams in coniferous forest belt. In pure mats or with Aneura pinguis, Anthelia juratzkana, Blepharostoma trichophyllum var. brevirete, Scapania irrigua, Tritomaria quinquedentata.

L. longidens (Lindb.) Macoun - gemm. - $765 \mathrm{~m}-$ Abies trunk base in coniferous forest belt. With Mylia verrucosa, Tritomaria exsecta (one collection).

L. savicziae Schljak. - gemm., per. - $2010 \mathrm{~m}$ - Cliff crevices in alpine belt. In pure mats or with Calypogeia sphagnicola.

L. silvicola $\mathrm{H}$. Buch - gemm. - $615 \mathrm{~m}$ - Wet decaying wood near stream, in partly shaded places, in coniferous forest belt. With Anastrophyllum michauxii, Blepharostoma trichophyllum var. trichophyllum, Cephalozia catenulata, Geocalyx cf. graveolens, Lepidozia reptans, Mylia verrucosa (one collection).

L. sudetica (Nees ex Hueb.) Grolle - gemm. - 870-2090 m Cliff crevices in open to partly shaded places. With Diplophyllum taxifolium, Herbertus dicranus, Lophozia ventricosa (Dicks.) Dumort. var. ventricosa, Marsupella alpina, M. tubulosa, Sphenolobus minutus.

L. ventricosa (Dicks.) Dumort. var. longiflora (Nees) Macoun - gemm. per. - 1880-2090 m - Crevices in cliffs and gravelly barrens, over mosses on flat cliff ledges, in alpine belt. In pure mats or with Cephalozia bicuspidata, Diplophyllum albicans, Pleurocladula albescens, Schistochilopsis grandiretis, S. opacifolia, Sphenolobus minutus, Tritomaria quinquedentata.

L. ventricosa (Dicks.) Dumort. var. ventricosa - gemm. - 1820$1930 \mathrm{~m}$ - Crevices in cliffs and gravelly barrens, over mosses in flat cliff ledges, in alpine belt. With Lophozia sudetica, Nardia insecta, Radula prolifera, Scapania crassiretis, Tritomaria quinquedentata.

Macrodiplophyllum microdontum (Mitt.) H.Perss. - gemm. 1920-2090 m - Crevices in gravelly barrens and cliffs, in alpine belt. In pure mats or with Apotreubia nana, Macrodiplophyllum plicatum, Mylia taylorii, Herbertus dicranus, Sphenolobus saxicola, Tritomaria quinquedentata.

M. plicatum (Lindb.) H.Perss. - gemm. - 1920-2090 m - Crevices in cliffs and gravelly barrens. - In pure mats or with Calycularia laxa, Diplophyllum taxifolium, Frullania subarctica, Herbertus dicranus, Macrodiplophyllum microdontum, Radula prolifera, Sphenolobus minutus, Tritomaria quinquedentata, etc.

Marchantia latifolia Gray - gemm. - 615 m - Wet boulder near stream. In pure mat (one collection).

Marsupella alpina (Gottsche ex Husn.) H.Bern. - ant., arch. $870(?), 1880-2010 \mathrm{~m}$ - Cliffs and their crevices in partly shaded to open places, in alpine belt (with one ambiguous identification from coniferous forest). Mostly in pure mats or (rarer) with Gymnomitrion corallioides, Herbertus dicranus, Lophozia sudetica, Marsupella tubulosa.

M. boeckii (Aust.) Lindb. ex Kaal. - ant., arch., per. - 1880$2010 \mathrm{~m}$ - Cliff surfaces and their crevices in mesic to moist conditions, in alpine belt. In pure mats or with Anthelia juratzkana, Marsupella commutata, M. tubulosa, Scapania parvifolia.

M. commutata (Limpr.) H.Bern. - arch. - 1920-2010 m - Crevices in cliffs and gravelly barrens filled with fine soil, bare soil in solifluction spots, in alpine belt. In pure mats or with Anthelia juratzkana, Diplophyllum albicans, Marsupella boeckii, M. tubulosa, Scapania parvifolia.

M. tubulosa Steph. - ant., per. - 615-2010 m - Moist to wet crevices in cliffs and gravelly barrens, mostly in alpine belt, but easily descending to coniferous forest belt along stream courses. In pure mats or with Calycularia laxa, Diplophyllum albicans, Gymnomitrion concinnatum, Lophozia sudetica, Scapania crassiretis, S. sphaerifera, Schistochilopsis opacifolia, Solenostoma pseudopyriflorum, Tritomaria quinquedentata, etc.

Metacalypogeia cordifolia (Steph.) H.Inoue - 610-870 m Moist cliffs in partly shaded places in coniferous forest belt. In pure mats or with Calycularia laxa, Diplophyllum obtusatum, D. taxifolium, Solenostoma pseudopyriflorum.

Metzgeria lindbergii Schiffn. - $870 \mathrm{~m}$ - Branches of Weigela, in partly shaded place. In pure mats (one collection).

M. temperata Kuwah. - gemm. $-615 \mathrm{~m}$ - Tree trunk in partly shaded sites in coniferous forest belt. In pure mats or with Frullania koponenii.

Mylia taylorii (Hook.) S. Gray - gemm. - 1820-2090 m - Moist Sphagnum mats in wet moss tundra; open cliff crevices in alpine belt. In pure mats or with Apotreubia nana, Macrodiplophyllum microdontum, Plagiochila arctica, Tritomaria quinquedentata.

M. verrucosa Lindb. - per., ant. - 540-870 m - Moist to wet decaying decorticated fallen wood in coniferous forest belt. 
In pure mats or with numerous generally epixylous taxa: Anastrophyllum michauxii, Calypogeia suecica, Cephalozia catenulata, C. leucantha, Crossocalyx hellerianus, Lepidozia reptans, Nowellia curvifolia, Riccardia palmata, Scapania apiculata, Schistochilopsis cornuta, or with more eurytopic Apometzgeria pubescens, Bazzania ovifolia, Blepharostoma trichophyllum var. trichophyllum, Lophozia longidens, L. silvicola, Riccardia latifrons, Tritomaria exsecta, etc.

Nardia insecta Lindb. - per., ant. - 1680-2050 m - Soil rich in humus near streams, soil covering rocks and mesic cliff crevices in open places, in alpine belt. In pure mats or with Cephalozia bicuspidata, Lophozia ventricosa, Solenostoma cf. rossica.

Nowellia curvifolia (Dicks.) Mitt. - per., ant. - 610-870 m Mesic to moist decaying decorticated wood in partly shaded places, in coniferous forest belt. In pure mats or with nearly the same species composition as Mylia verrucosa (Anastrophyllum michauxii, Blepharostoma trichophyllum var. trichophyllum, Cephalozia catenulata, Crossocalyx hellerianus, Lepidozia reptans, Riccardia palmata, Scapania apiculata, etc.).

Pellia neesiana (Gott.) Limpr. - ant. - 1680-1885 m - Moist crevices in cliffs and gravelly barrens in open places, in alpine belt. - In pure mats or with Scapania spitsbergensis, Schistochilopsis opacifolia, Tritomaria quinquedentata.

Peltolepis quadrata (Saut.) Müll.Frib. - ant., arch., spor. 1850-1940 m - Mesic to moist cliff caves and large crevices in alpine belt. In pure mats or with Aneura pinguis, Anthelia juratzkana, Blepharostoma trichophyllum var. trichophyllum, Diplophyllum taxifolium, Lophozia lantratoviae, Plagiochila porelloides, Tritomaria quinquedentata, Preissia quadrata, Sauteria alpina.

Plagiochila arctica Bryhn et Kaal. - 1940-2090 m - Moist cliff crevices and flat cliff ledges covered with hygrophilic mosses, in partly shaded to open places, in alpine belt. In pure mats or with Apotreubia nana, Calycularia laxa, Mylia taylorii, Scapania crassiretis, Tritomaria quinquedentata.

P. ovalifolia Mitt. - $615 \mathrm{~m}$ - Wet decaying wood near stream, in partly shaded place, in coniferous forest belt. In pure mat (one collection).

P. porelloides (Torrey ex Nees) Lindenb. - 760-1940 m - Mesic to wet cliffs in partly shaded to open sites, wet boulders near streams, bare humus on steep slopes, in coniferous forest belt to alpine belt. In pure pats or with Aneura pinguis, Apometzgeria pubescens, Blepharostoma trichophyllum var. brevirete, Blepharostoma trichophyllum var. trichophyllum, Peltolepis quadrata, Radula prolifera, Tritomaria quinquedentata. - In studied area the species occupies large altitudinal scale 'touching' in lowland temperate Plagiochila ovalifolia, but in alpine belt meeting basophilic cryophyte $P$. arctica, some forms intergrades to both of mentioned taxa and relationships between all of three species should be checked genetically.

Plectocolea obscura A. Evans - ant., per. - 610-1890 m-Moist to wet cliffs and stones near streams and wet crevices in gravelly barrens beside streams, in partly shaded places, from coniferous forest belt to alpine belt. In pure mats or with Anthelia juratzkana, Cephalozia bicuspidata, Scapania crassiretis, Solenostoma pseudopyriflorum, S. rossicum.

Pleurocladula albescens (Hook.) Grolle - 1850-1890 m-Mesic cliff crevices in open places, in alpine belt. With Anthelia juratzkana and Lophozia ventricosa var. longiflora.

Porella vernicosa Lindb. - $615 \mathrm{~m}$ - Mesic open cliff. - In pure mat (one collections).

Preissia quadrata (Scop.) Nees - arch. - 1680-2050 m - Mesic cliff caves, moist cliff crevices, crevices between stones in gravelly barrens, in alpine belt. In pure mats or with Peltolepis quadrata, Sauteria alpina, Tritomaria quinquedentata.

Ptilidium pulcherrimum (G.Web.) Vain. - $615 \mathrm{~m}$ - Wet decaying wood near stream, in part shade. With Barbilophozia barbata, Scapania apiculata, Tritomaria exsecta (one collection).

P. ciliare (L.) Hampe - 1920-1940 m - Among mosses in mountain tundras, over mosses in flat cliff ledges, in alpine belt. In pure mats or with Tritomaria quinquedentata.

Radula complanata (L.) Dumort. - per., ant., spor. - 540-870 $\mathrm{m}-$ Abies trunks and branches, branches of Weigela, in coniferous forest to subalpine shrubs. - In pure mats or with Apometzgeria pubescens.

R. prolifera Arnell - per. - 1940-2090 m - Mesic to moist cliff crevices in open places, over mosses on flat cliff ledges, in partly shaded places, in alpine belt. In pure mats or with Aneura pinguis, Bazzania tricrenata, Blepharostoma trichophyllum var. brevirete, Frullania subarctica, Herbertus dicranus, Macrodiplophyllum plicatum, Plagiochila porelloides, Scapania crassiretis, Sphenolobus minutus, T. quinquedentata, etc.

Reboulia hemisphaerica (L.) Raddi ssp. orientalis R.M. Schust. - ant., arch. - $615 \mathrm{~m}$ - Mesic cliffs in open place, in coniferous forest belt. In pure mat (one collection).

Riccardia latifrons (Lindb.) Lindb. - $870 \mathrm{~m}$ - Decaying decorticated mesic wood in partly shaded places, in coniferous forest belt. With Mylia verrucosa, Nowellia curvifolia (one collection).

R. palmata (Hedw.) Carruth. - arch. $-615-870 \mathrm{~m}-$ Moist to wet (also near streams) decaying decorticated wood, in partly shaded plaves, in coniferous forest belt. With Anastrophyllum michauxii, Calypogeia suecica, Cephalozia catenulata, C. lunulifolia, Geocalyx cf. graveolens, Lepidozia reptans, Mylia verrucosa, Nowellia curvifolia, Scapania apiculata, etc.

Sauteria alpina (Nees) Nees - ant., arch., spor. - $1850 \mathrm{~m}-$ Cliff caves in partly shaded places, in alpine belt. - In pure mats or with Blepharostoma trichophyllum var. trichophyllum, Peltolepis quadrata, Preissia quadrata, Schistochilopsis opacifolia.

Scapania apiculata Spruce - gemm., per. - 540-870 m - Mesic to wet (also near streams) decaying decorticated (or rarely barked) wood in partly shaded places, in coniferous forest belt. In pure mats or with Anastrophyllum michauxii, Calypogeia suecica, Cephalozia bicuspidata, C. leucantha, Crossocalyx hellerianus, Geocalyx graveolens, Lophocolea heterophylla, Mylia verrucosa, Nowellia curvifolia, Riccardia palmata, Tritomaria exsecta, etc.

S. cf. lingulata $\mathrm{H}$. Buch - gemm. - $2090 \mathrm{~m}$ - Crevice in gravelly barrens in partly shaded place, in alpine belt. In pure mat (one collection).

S. crassiretis Bryhn - gemm., per. - 610-2050 m - Moist to wet cliff crevices, also near streams, flat cliff ledges, moist crevices in gravelly barrens, in coniferous forest to alpine belts. In pure mats or with Aneura pinguis, Anthelia juratzkana, Cryptocolea imbricata, Frullania subarctica, Lopho- 
zia ventricosa var. ventricosa, Marsupella tubulosa, Plagiochila arctica, Radula prolifera, Scapania spitsbergensis, Schistochilopsis opacifolia, Solenostoma pseudopyriflorum, S. rossicum, T. quinquedentata, etc.

S. diplophylloides Amakawa et S. Hatt. - per. - $765 \mathrm{~m}-$ Mesic cliffs in partly shaded places, in coniferous forest belt. In pure mat (one collection).

S. gymnostomophila Kaal. - gemm. - 1940 m - Mesic cliff crevice in open place, in alpine belt. In pure mat (one collection).

S. irrigua (Nees) Nees - gemm. - 760-1690 m - Soil rich in humus and boulders near streams, in coniferous to alpine belts. - In pure mats or with Lophozia lantratoviae.

S. mucronata H. Buch - gemm. -610-1940 m-Mesic to moist cliff crevices in open places, in coniferous to alpine belts. With Herbertus dicranus, Schistochilopsis opacifolia, Sphenolobus minutus, Tritomaria exsecta, T. quinquedentata.

S. parvifolia Warnst. - per. - 760-2090 m - Mesic cliff crevices, over mosses on flat cliff ledges, over peat in mossy mountain tundras, mostly in alpine belt, rarely descending to coniferous forest belt along streams. In pure mats or with $A n$ thelia juratzkana, Cephalozia bicuspidata, C. pleniceps, Marsupella boeckii, Marsupella commutata, Radula prolifera, Sphenolobus minutus.

S. sphaerifera H. Buch. - gemm. - $1930 \mathrm{~m}-$ Crevices in gravelly barrens, in partly shaded to open sites, in alpine belt. With Marsupella tubulosa, Tetralophozia setiformis.

S. spitsbergensis (Lindb.) Tuomik. - gemm., per., ant. - 765, 1680-2090 m - Crevices in gravelly barrens in alpine belt; rarely on stones along stream in coniferous forest belt. With Pellia neesiana, Scapania crassiretis, Tritomaria quinquedentata.

S. subalpina (Nees ex Lindenb.) Dumort. - gemm. - $615 \mathrm{~m}-$ Wet boulders and decaying wood along stream in coniferous forest belt. In pure mats.

Schistochilopsis cornuta (Steph.) Konstant. - gemm., per. 540-770 m - Mesic to moist decaying decorticated wood in part shade, in coniferous forest belt. In pure mats or with Calypogeia integristipula, Cephalozia catenulata, Mylia verrucosa, Tritomaria exsecta.

S. grandiretis (Lindb. ex Kaal.) Konst. - gemm. - 1940 m Flat cliff ledge, over mosses (mostly Sphagnum) in open place, in alpine belt. - With Cephalozia bicuspidata, Lophozia ventricosa var. longiflora, Schistochilopsis opacifolia, Sphenolobus minutus (one collection).

S. incisa (Schrad.) Konst. $-1930 \mathrm{~m}-$ Crevice in gravelly barrens, in alpine belt. - In pure mat (one collection).

S. opacifolia (Culm. ex Meyl.) Konst. - gemm. - 1680-2090 m - Cliff crevices mostly filled with fine soil and crevices between stones in gravelly barrens, along streams, in open to partly shaded places, in alpine belt. With Cephalozia bicuspidata, Lophozia ventricosa var. longiflora, Marsupella tubulosa, Pellia neesiana, Sauteria alpina, Sphenolobus minutus, Tritomaria quinquedentata etc.

Solenostoma confertissimum (Nees) Schljak. - per., ant. - 1940 $\mathrm{m}-$ Moist cliff crevice in open place, in alpine belt. In pure mats (one collection).

S. pseudopyriflorum Bakalin et Vilnet - per., ant. - 610-770 m - Moist to wet cliffs near or beside stream, in coniferous forest belt. In pure mats or with Diplophyllum obtusatum, D. taxifolium, Marsupella tubulosa, Metacalypogeia cordifolia, Plectocolea obscura, Scapania crassiretis.
S. rossicum Bakalin et Vilnet - per. - 1680-1930 m - Crevices in cliffs and gravelly barrens, edges of solifluction spots, soil rich in humus along small stream, in alpine belt. In pure mats or with Anthelia juratzkana, Cephalozia bicuspidata, Nardia insecta, Plectocolea obscura, Scapania crassiretis.

Sphenolobus minutus (Schreb.) Berggr. - gemm., ant., per. 610-2090 m-Cliffs and cliff crevices, crevices in gravelly barrens, flat cliff ledges, in partly shaded to open places, from coniferous forest belt to alpine belt. In pure mats or with Bazzania ovifolia, Calycularia laxa, Cephalozia bicuspidata, C. pleniceps, Diplophyllum taxifolium, Lophozia sudetica, L. ventricosa var. longiflora, Macrodiplophyllum plicatum, Schistochilopsis grandiretis, S. opacifolia, Sphenolobus saxicola, Tritomaria exsecta, T. quinquedentata, etc.

S. saxicola (Schrad.) Steph. - 1850-2090 m - Cliffs, mesic crevices in cliffs and gravelly barrens, in partly shaded to open places, in alpine belt. In pure mats or with Diplophyllum taxifolium, Frullania subarctica, Herbertus dicranus, Macrodiplophyllum microdontum, Tritomaria quinquedentata.

Tetralophozia setiformis (Ehrh.) Schljak. - 1930-2090 m Crevices in gravelly barrens and dry cliff ledges. In pure mats or with Diplophyllum albicans, Gymnomitrion concinnatum, Marsupella tubulosa, Scapania sphaerifera, Tritomaria quinquedentata.

Tritomaria exsecta (Schmid. ex Schrad.) Loeske - gemm., per. $-610-2010 \mathrm{~m}-$ Mesic to moist partly shaded decaying wood and trunk bases, cliffs in open places, from coniferous forest belt to alpine belt. In pure mats or with epixylous (Cephalozia catenulata, C. leucantha, Lepidozia reptans, Mylia verrucosa, etc.), generally epilithic (Frullania subarctica, Herbertus dicranus, Radula prolifera, Scapania crassiretis, Sphenolobus minutus, etc.) or more eurytopic taxa (Aneura pinguis, Blepharostoma trichophyllum var. trichophyllum, Calypogeia integristipula, Cephalozia bicuspidata, Lophozia longidens, etc)

T. quinquedentata (Huds.) H. Buch - per., spor. $-610-2090 \mathrm{~m}$ - Moist to wet cliffs and their crevices, crevices in gravelly barrens, over mosses on flat cliff ledges, in open to partly shaded places. In pure mats or with Aneura pinguis, Anthelia juratzkana, Apotreubia nana, Blepharostoma trichophyllum var. brevirete, Calycularia laxa, F. subarctica, Gymnomitrion concinnatum, Lophozia lantratoviae, Macrodiplophyllum plicatum, Marsupella tubulosa, Mylia taylorii, Pellia neesiana, Peltolepis quadrata, Radula prolifera, Scapania crassiretis, $S$. spitsbergensis, Schistochilopsis opacifolia, Sphenolobus minutus, Tritomaria exsecta, etc.

\section{DISCUSSION}

Altogether, the study revealed 106 hepatic species; among them 24 species are new for Sikhote-Alin mountain system. The diversity of hepatics was found to be quite high and considerably different in various altitudinal belts. The study has highlighted Tardoki-Yani as the taxonomically richest southern refugium of arctic-alpine hepatic flora in East Asia. The following discussion describes some features of this area and its hepatic flora.

\section{Habitats}

Two main species groups determine the general character of the hepatic flora in the studied area: an epixylous complex of coniferous forests and a cliff epilithic 
one in alpine belt. Other complexes are represented much weaker.

The core of epixylous taxa includes Anastrophyllum michauxii, Mylia verrucosa, Nowellia curvifolia. Other obligate epixylous taxa, being however slightly to considerably rarer are Calypogeia suecica, Cephalozia catenulata, Crossocalyx hellerianus, Scapania apicula$t a$, to that Riccardia palmata is added in wetter conditions. Among the facultative epixilous species can be mentioned Apometzgeria pubescens, Cephalozia leucantha, Cephalozia otaruensis, Cephaloziella rubella, Frullania bolanderi, Geocalyx graveolens, Lophocolea heterophylla, Lophocolea minor, Lophozia silvicola, Plagiochila ovalifolia, Riccardia latifrons and Schistochilopsis cornuta.

Aneura pinguis joins two main habitat types in the area: decaying wood in coniferous forests and moist cliffs in alpine belt. This is the specific character of the species in the south of the Russian Far East (as well as southward in temperate East Asia), but is strongly unusual for the rest of Russia. When in low elevation the species occurs as typical epixylous, forming pure mats or growing in the mixture with obligate epixylous taxa, in upper elevations it commonly grows with arctic-alpine taxa, such as $A n$ thelia juratzkana, etc. Other taxa sharing both epixylous and epilithic habitats are Bazzania ovifolia, Blepharostoma trichophyllum var. trichophyllum, Lepidozia reptans, Tritomaria exsecta. Bazzania trilobata grows both on strongly decaying wood and soil rich in humus on slopes (then forming ground cover). Occasional ( alien) participants of epixylous synusia are Barbilophozia barbata on dry wood and Scapania crassiretis, S. subalpina on wet decaying wood near streams. Eurytopic species occasionally occurring on decaying wood are Calypogeia integristipula, Cephalozia bicuspidata, C. lunulifolia.

The core of epilithic formation depends on elevation, being more diverse at higher altitude and is represented at low elevation mostly as an impoverished 'alpine' fraction. There is also noticeable difference between cliffs along streams wetted by running water and dry cliffs in open places, but the evident border between these two kinds of communities is loose.

Most dry rocky habitats are inhabited by Sphenolobus saxicola and Tetralophozia setiformis, although both species occur (fairly rarer) in mesic habitats too. Alpine belt cliffs in dry to mesic conditions house Anthelia juratzkana, Apometzgeria pubescens, Bazzania tricrenata, Blepharostoma trichophyllum var. brevirete, B. trichophyllum var. trichophyllum, Calycularia laxa, Calypogeia integristipula, Cephalozia pleniceps, Cephaloziella hampeana, Diplophyllum albicans, D. taxifolium, Frullania subarctica, Gymnomitrion concinnatum, $G$. corallioides, Herbertus dicranus, Leiocolea heterocolpos, Lejeunea alaskana, Lophozia sudetica, L. ventricosa var. longiflora, Macrodiplophyllum microdontum, M. plicatum, Mylia taylorii, Marsupella alpina, M. bo- eckii, M. commutata, M. tubulosa, Nardia insecta, Plagiochila porelloides, Plectocolea obscura, Preissia quadrata, Radula prolifera, Scapania gymnostomophila, S. parvifolia, S. sphaerifera, Solenostoma rossicum, Sphenolobus minutus, S. saxicola, Tetralophozia setiformis, Tritomaria exsecta and T. quinquedentata. Rarely on mesic cliffs xeric forms of Scapania crassiretis were found, while the species is fairly common in much wetter habitats, as well as Lophozia lantratoviae (similar there to L. longidens). Frullania davurica was found twice in alpine belt, on mesic cliffs, but the species is fairly more common on trunks at low elevations.

Flora of moist to wet cliffs is richer and counts 23 species including Anthelia juratzkana, Aneura pinguis, Apotreubia nana, Calypogeia sphagnicola, Cryptocolea imbricata, Diplophyllum albicans, Gymnomitrion concinnatum, Jungermannia pumila, Lophozia lantratoviae, L. savicziae, L. ventricosa var. longiflora, Macrodiplophyllum plicatum, Marsupella boeckii, M. tubulosa, Mylia taylorii, Pellia neesiana, Plagiochila porelloides, Pleurocladula albescens, Scapania crassiretis, $S$. spitsbergensis, Schistochilopsis opacifolia, Solenostoma confertissimum and Tritomaria quinquedentata.

Flat cliff ledges in alpine belt bear rather distinctive flora that houses several 'northern' taxa such as Radula prolifera or more or less rare species in the south of the Russian Far East: Apotreubia nana, Blepharostoma trichophyllum var. brevirete, Herbertus dicranus, Plagiochila arctica, Schistochilopsis grandiretis, S. opacifolia, as well as rather common Calycularia laxa, Cephalozia bicuspidata, Lophozia ventricosa var. longiflora, Mylia taylorii, Ptilidium ciliare, Scapania crassiretis, Sphenolobus minutus.

Special habitat are niches in the caves and crevices filled by fine soil in alpine belt. Here occur Blepharostoma trichophyllum var. trichophyllum, Calycularia laxa, Diplophyllum taxifolium, Peltolepis quadrata, Preissia quadrata, Plagiochila porelloides, Sauteria alpina, Schistochilopsis opacifolia, Tritomaria quinquedentata.

Mesic to moist cliffs at low elevations house Barbilophozia barbata, Bazzania ovifolia, Calycularia laxa, Diplophyllum obtusatum, D. taxifolium, Herbertus dicranus, Lepidozia reptans, Lophozia sudetica, Metacalypogeia cordifolia, Marsupella tubulosa, Plectocolea obscura, Porella vernicosa, Reboulia hemisphaerica ssp. orientalis, Scapania crassiretis, S. diplophylloides, S. mucronata, S. parvifolia, Solenostoma pseudopyriflorum, Sphenolobus minutus, Tritomaria exsecta and T. quinquedentata.

Stream banks (with at least occasional impact of running water) have rather diverse flora that may be divided into three main sections: 1) decaying wood, with Lophozia silvicola, Geocalyx graveolens, Plagiochila ovalifolia, Scapania crassiretis and Scapania subalpina in low elevation, 2) soil rich in humus, with Lophozia lantratoviae, Marchantia latifolia, Scapania irrigua at low ele- 
vation and Cephalozia bicuspidata, Nardia insecta and Solenostoma rossicum at higher elevation, 3) stones, with Diplophyllum obtusatum, Jungermannia exsertifolia, Liochlaena subulata, Lophozia lantratoviae, Marsupella tubulosa, Metacalypogeia cordifolia, Plagiochila porelloides, Plectocolea obscura, Scapania crassiretis, S. irrigua, S. spitsbergensis, S. subalpina and Solenostoma pseudopyriflorum at low elevation and with very similar composition to that of the moist cliff in higher elevation.

Tree trunks house the most southern elements in the flora, such as Cololejeunea macounii, Lejeunea japonica, Metzgeria temperata, as well as more northerly distributed, although represented in most cases by southern relations of the flora: Apometzgeria pubescens, Frullania davurica, Frullania koponenii, Radula complanata. Tree bases house Mylia verrucosa, Tritomaria exsecta as well as Lophozia longidens - the common component of boreal coniferous forests (taiga), but exceptionally rare in southern part of the Russian Far East.

\section{Altitudinal patterns}

Certainly, taxonomic composition is not the same in different vegetation belts. In the practice, two belts may be revealed in the studied area: coniferous forests and alpine. Subalpine belt and birch crooked forests are not apparent (cf. Vyshin, 1990). They largely spread among numerous small ridges (spurs of the main range) both to forest zone down and alpine one upward, but have no exact elevation range, at least in the study area. As it was pointed out by Vyshin (1990), the upper level of crooked forests in the northern Sikhote-Alin was found at the elevation of $1500 \mathrm{~m}$, but the lowest level of mountain tundra is at $800 \mathrm{~m}$ a.s.1. The taxonomic composition of bryophyte communities of subalpine belt is rather poor and represented by a strongly impoverished mixture of forest and alpine elements. Thus in the following discussion I recognize just two belts: forest and alpine. Species found in subalpine communities are regarded as representatives of one or both of two aforementioned belts taking into account habitats and distribution 'core' of the species aside subalpine communities.

In total flora of Tardoki-Yani counts 108 hepatic taxa (106 species, two of them are represented by two varieties: Lophozia ventricosa var. ventricosa and var. longiflora and Blepharostoma trichophyllum var. trichophyllum and var. brevirete, treated separately in the following account. Forty one taxa are limited by forest belt, 45 - by alpine one and 22 species are distributed across both. Therefore, the distinction between two belts is noticeable. Forest belt is specified by many epixylous taxa, while the alpine belt houses arctic-alpine epilithic species.

Some species are restricted to the forest belt and distributed throughout it, e.g., Anastrophyllum michauxii, Lepidozia reptans, Metacalypogeia cordifolia, Nowellia curvifolia, Scapania apiculata, while south temperate species occur only at low elevations, e.g. Cololejeunea macounii, Frullania koponenii, Metzgeria temperata, Plagiochila ovalifolia.

Upper limits of alpine belt house several rare taxa, such as Apotreubia nana or arctic-alpine species, having here southern outposts of the area (Cryptocolea imbricata, Gymnomitrion spp., Lejeunea alaskana, Lophozia savicziae, Marsupella boeckii, Plagiochila arctica, Pleurocladula albescens, etc.) or at least being generally more northern in distribution (Jungermannia pumila, Leiocolea heterocolpos, Macrodiplophyllum microdontum, Peltolepis quadrata, Ptilidium ciliare, Sauteria alpina, etc.).

Altitudinal potential is not realized for the majority of alpine taxa, and occurring diapason is limited by absolute elevations as well as relatively dry conditions in areas near the peaks. The mesic crevices in gravelly barrens very near to top of the studied area (2085-2090 m) house 28 taxa: Apotreubia nana, Blepharostoma trichophyllum var. brevirete, Calycularia laxa, Calypogeia integristipula, Cephalozia pleniceps, C. bicuspidata, Diplophyllum albicans, Gymnomitrion concinnatum, Herbertus dicranus, Lophozia ventricosa var. longiflora, L. sudetica, Macrodiplophyllum microdontum, $M$. plicatum, Marsupella alpina, M. commutata, M. tubulosa, Mylia taylorii, Plagiochila arctica, Radula prolifera, Scapania crassiretis, S. cf. lingulata, S. parvifolia, S. spitsbergensis, Schistochilopsis opacifolia, Sphenolobus minutus, S. saxicola, Tetralophozia setiformis and Tritomaria quinquedentata. This is a rather heterogeneous group reflecting that not temperature, but other conditions determine distribution of many hepatics in alpine belt in the studied area.

Some species, distributed across the whole altitudinal range, change ecology, e.g., Aneura pinguis, Apometzgeria pubescens are epixylous at low elevations, but become epilithic above. In some other taxa, e.g. Barbilophozia barbata, Tritomaria exsecta, this regularity is not obvious (they occur on cliffs at low elevation too), and probably they do not occur on decaying wood in alpine belt simply because of the absence of such substrate in the latter.

At the generic level, some genera are limited to one belt, whereas others are represented by different (sometimes related) species in forest zone and alpine belts. For example, Bazzania has two species (B. trilobata, B. ovifolia) distributed below $770 \mathrm{~m}$, and one (B. tricrenata) present only above $1820 \mathrm{~m}$, in alpine tundra belt. Blepharostoma trichophyllum has one variety limited by tundra belt (var. brevirete) and one (var. trichophyllum) distributed in both. Calypogeia has one species (C. suecica) distributed in forests, one (C. sphagnicola) limited to the alpine belt and one ( $C$. integristipula) occurs in both. Cephalozia has five species, with one (C. bicuspidata) common in both belts, three (C. leucantha, $C$. catenulata and $C$. otaruensis) limited to forests and one (C. pleniceps) to the alpine belt. It is worth to note, the 

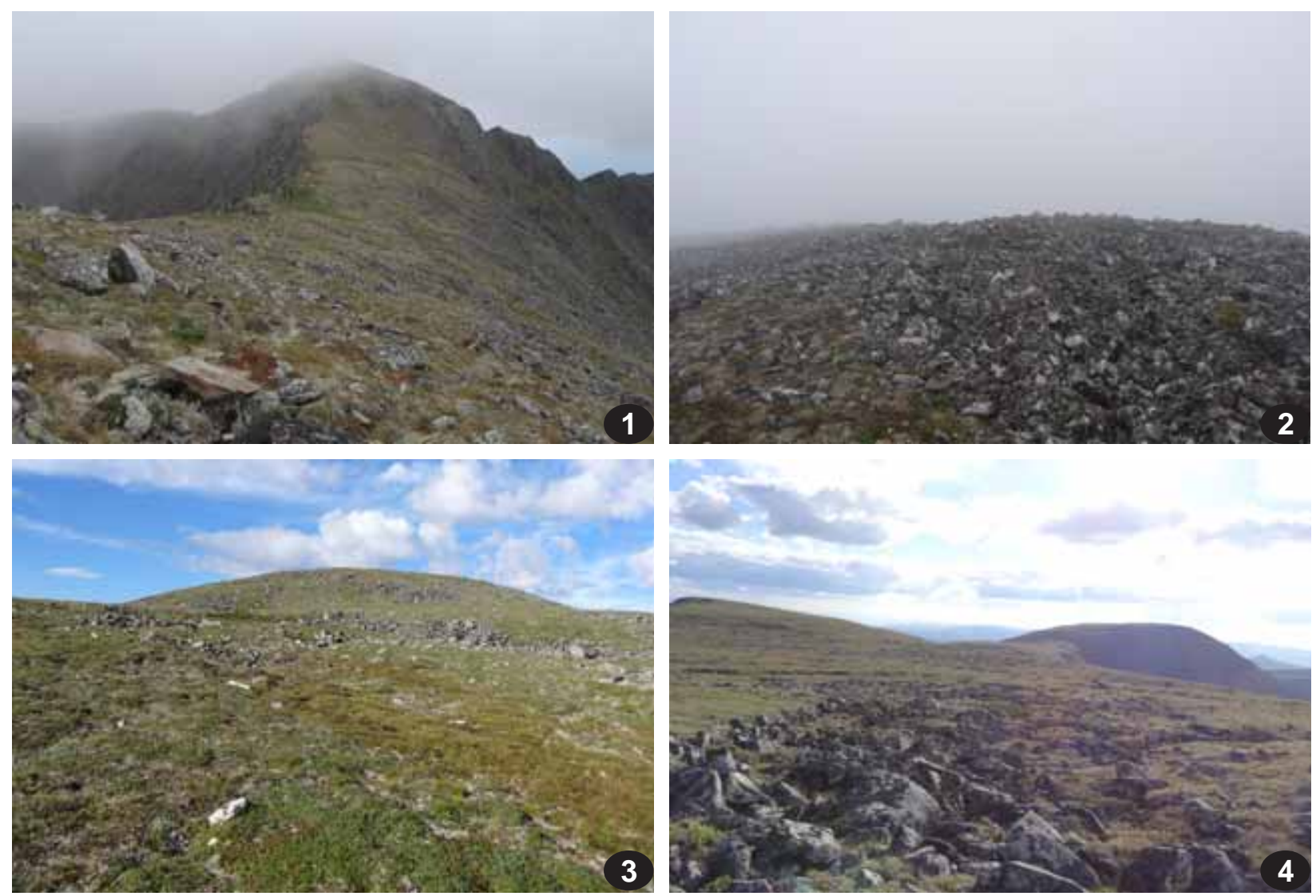
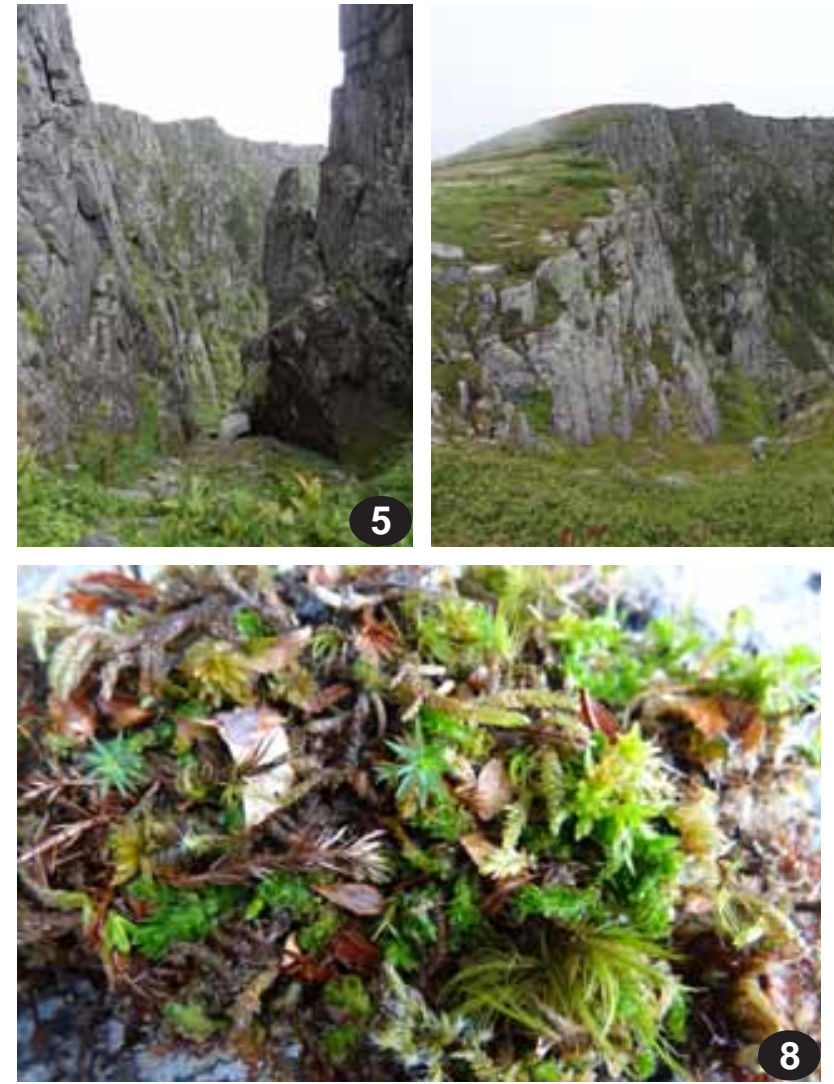

Figs. 1-9. Upper elevations of the Tardoki-Yani Mt.: 1: ridge near main peak of $2090 \mathrm{~m}$ (photo at $1950 \mathrm{~m}$ ); 2: gravelly barrens near the top $(2000 \mathrm{~m}) ; 3$ : dwarf shrub-mossy tundra $(1700 \mathrm{~m})$; 4: flattened surface near ridge top (1850 m); 5: narrow cleft in alpine belt $(1800 \mathrm{~m}) ; 6$ : bluff on west slope of the range $(1850 \mathrm{~m})$; 7: steep slopes to mountain circus (1900 m); 8: Apotreubia nana from crevice in $7(1900 \mathrm{~m})$; 9: Oedipodium griffithianum from crevice in 5 (1900 m); all photographs are by Mr. A. Ermolenko. 

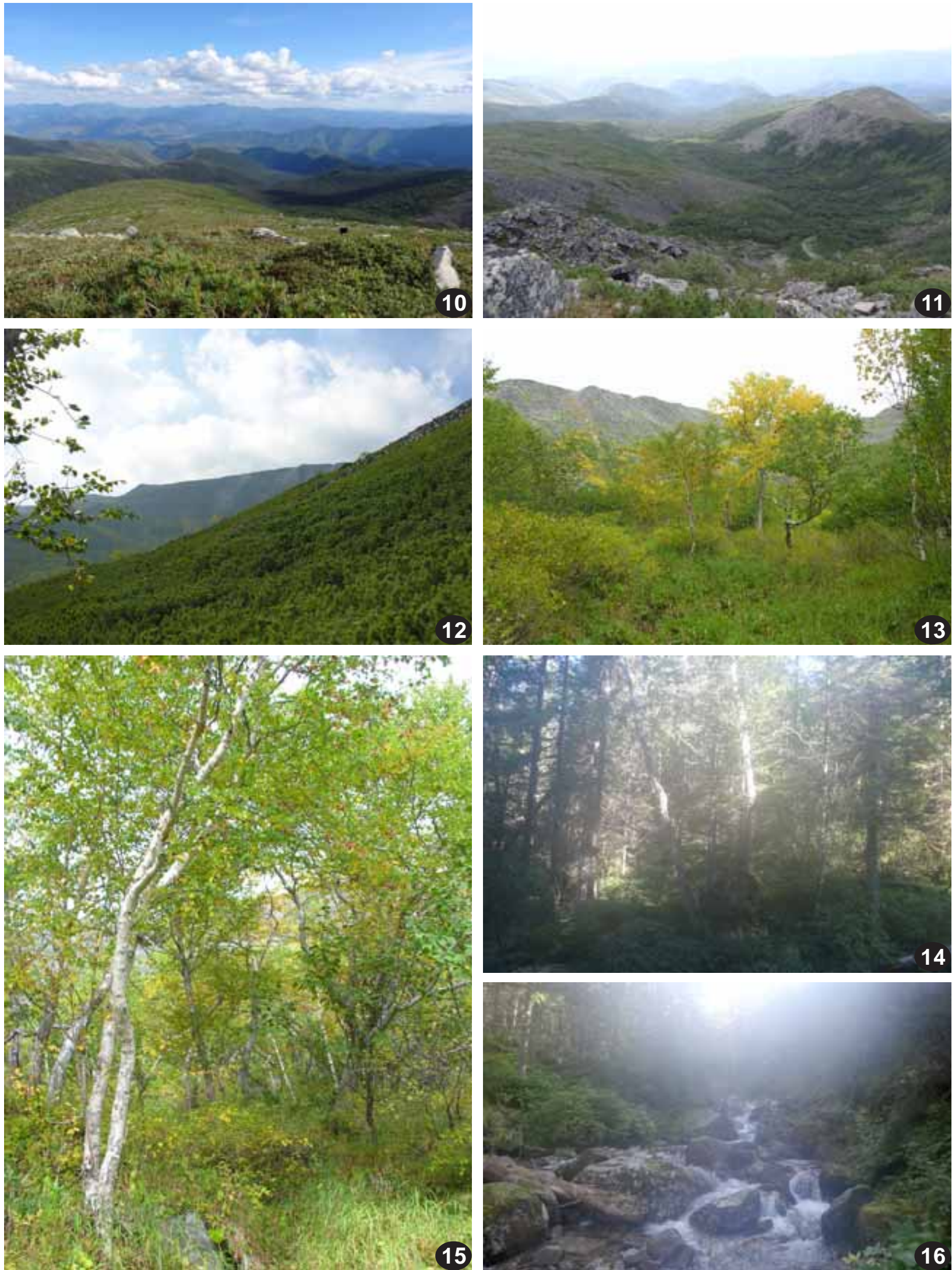

Figs. 10-16. Tardoki-Yani Mt., vegetation at various elevations: 10: southern spurs of the range (1600 m); 11: valley with Betula lanata forest in its bottom $(1700 \mathrm{~m}) ; 12$ : Pinus pumila thickets $(1700 \mathrm{~m}) ; 13$ \& 15: Betula lanata forest in mountain circus (1500 m); 14 \& 16: coniferous forest (Abies nephrolepis prevalis) in foothills (600 m); photographs by Dr. V. Barkalov (12$13,15)$ and by Mr. A. Ermolenko (10-11, 14, 16). 
peculiarity of distribution pattern of $C$. pleniceps in the southern part of the Russian Far East. In other regions of Russia this species is common in both forest and alpine belts (being much more common at low altitude), in the south of the Russian Far East, this is the species of strictly alpine habitats. I see the only explanation of this fact in the 'occupancy' of suitable habitats for the species by other taxa of the genus (three listed above) as well as other genera (e.g. Nowellia curvifolia) that prevent its occurrence at low altitude.

Diplophyllum has three species with one (D. obtusatum) limited by forest belt, one (D. albicans) by alpine belt and one (D. taxofolium) distributed in both. Frullania has two species in forests (F. bolanderi, F. kopone$n i i)$, one (F. subartica) in alpine belt and one (F. davuri$c a)$ in the both. Lejeunea has one species in forests ( $L$. japonica) and one in alpine belt (L. alaskana). Mylia has one species (M. verrucosa) in forest belt and one ( $M$. taylorii) in alpine belt. Plagiochila has three species, with one in forests $(P$. ovalifolia), one $(P$. arctica) in alpine tundra and one ( $P$. porelloides) both. Radula has two species with $R$. prolifera in alpine belt and $R$. complanata - in forests. Scapania has 11 species with 3 (S. apiculata, S. diplophylloides, S. subalpina) in forest belt, 3 ( $S$. gymnostomophila, S. lingulata, S. sphaerifera) in alpine tundras and 5 (S. crassiretis, S. irrigua, S. mucronata, $S$. parvifolia, $S$. spitsbergensis) in both. Schistochilopsis has one species at low elevation (S. cornuta) and two (S. grandiretis and $S$. incisa) in alpine belt. The pattern of $S$. incisa is strikingly similar to the aforementioned for Cephalozia pleniceps. Outside of southern flank of the Russian Far East, Schistochilopsis incisa is the common participant of coniferous forest communities (especially decaying wood), but here limited by alpine belt, probably due to 'occupancy' of suitable habitat by closely related East Asian S. cornuta.

\section{Phytogeographic considerations}

Analyzing distribution of hepatics in the Far East, Bakalin (2010) highlighted two general patterns: 1) within the insular part, including Kamchatka, Kurils, and Japan, changes in the flora composition from north to south are more gradual than in the continental part along the line from Magadan Province, Khabarovsk and Primorsky Territories, Korean Peninsula; also, the northern species penetrate farther to the south in the insular part than in the continental one, 2) number of species specific for insular area is noticeably higher than for the continental one. Another expected peculiarity is that the number of arctic-alpine taxa (e.g., Gymnomitrion spp.) have the gap in the southern part of the Russian Far East occurring in Sorak Mts. of Korean Peninsula, and then, after a considerable disjunction, in Magadan Province or in Bureya River Basin, separated by 2000-3000 km distance. This might support the hypothesis that exchange between 'North' and 'South' in boreal and temperate East Asia had the only way: Honshu (with branch to Korean
Peninsula) - Hokkaido - Kurils (with branch to Sakhalin and Dzhugdzhur Range) - Kamchatka - Chukotka. The evidences supporting this hypothesis are the presence of obvious refugia of periglacial flora on the way (cf. Bakalin et al., 2012).

The similar opinion was revealed for vascular plants. Analyzing Sikhote-Alin highland vascular plant flora, Vyshin (1990) showed that the latter has common species with Changbai Mts. mostly in the montane flora elements, but not in the group of highland, or "arctic-alpine," species. Some arctic-alpine taxa occur in Changbai Mts. and in the North Sikhote-Alin, being absent in Middle and South Sikhote-Alin. Thus Vyshin (1.c.) rejected the possibility of direct migrations of arctic-alpine taxa on the way North Sikhote-Alin - Middle and South Sikhote-Alin - Changbai Mts, although earlier Kharkevich \& Vyshin (1984) admitted that in the glacial periods alpine and arcto-alpine species penetrated freely to the upper mountain belts of the Sikhote-Alin Range.

According to botanico-geographical subdivision of the Khabarovsk Territory, Shlotgauer et al. (2001) referred Tardoki-Yani Range to the Circumboreal Floristic Province, but not to the East Asian one, probably due to abundance of boreal and alpine taxa in upper belts of the mountains. Indeed, Tardoki-Yani represents the mixture of temperate East Asian elements in lower belt, then circumpolar boreal in the middle and arctic-alpine in the upper one. Some bryophyte records of south temperate taxa in Tardoki-Yani represent the northernmost outposts of the species area. The occurrence of the latter may be easily explained by continuous band of habitats appropriate for the species such as Lejeunea japonica and Cololejeunea macounii. This highly correlates with general distribution of vascular plants, where northern Sikhote-Alin is the northernmost outpost of distribution for a number of taxa such as Phellodendron amurense Rupr., Juglans mandshurica Maxim., Maackia amurensis Rupr., Syringa amurensis Rupr., Arisaema amurense Maxim., etc. (Shlotgauer et al., 2001).

No temperate taxa new to Sikhote-Alin were found in the study area, although four species were revealed here for the first time for low elevations of this mountain system: boreal epixylous Crossocalyx hellerianus, oreoboreal mostly Asian-American epilithic Diplophyllum obtusatum, arcto-boreal Lophozia longidens and arctoboreal Nardia insecta.

Doubtless, the most interesting records in TardokiYani Range are among arctic-alpine species. Being a part of the continuous mountain system however with "only certain forestless peaks..., stand out against a taiga" (Kurentsov, 1967: 67), the only Tardoki-Yani Range provides a large area for alpine tundra vegetation (at least among studied), with the set of arctic-alpine species. In total, 20 alpine taxa were found in Sikhote-Alin in Tardoki-Yani Range only. These are arctic-alpine Anthelia juratzkana, Blepharostoma trichophyllum var. brevirete, 
Cephaloziella hampeana, Frullania subarctica, Gymnomitrion concinnatum, Gymnomitrion corallioides, Lejeunea alaskana, Lophozia savicziae, Marsupella alpina, M. boeckii, Plagiochila arctica, Pleurocladula albescens, Radula prolifera, Sauteria alpina, Scapania gymnostomophila, S. spitsbergensis and Schistochilopsis grandiretis, alpine East Asian Apotreubia nana, north boreal Calypogeia sphagnicola, and arcto-boreal CircumOkhotsk recently described Solenostoma rossicum.

The comparison of this list with the list of hepatics known for Changbai Mts. (Söderström, 2000; Koponen et al., 1983; Gao \& Cao, 1983) revealed only two species of the latter 'alpine' fraction (Anthelia juratzkana, Calypogeia sphagnicola) common with the Tardoki-Yani Mts. flora. Two more species, Gymnomitrion concinnatum and G. corallioides, occur at highest elevations of South Korea (Anonymous, 2013), but not recorded (although, I think, must be present) in Changbai Mts. No common species of the listed are known in Jilin and Heilongjiang Provinces of China (aside two aforementioned for Changbai Mts.). The largest number (eight) of listed taxa are known in Japan: Anthelia juratzkana, Gymnomitrion concinnatum, Gymnomitrion corallioides, Marsupella alpina, Marsupella boeckii, Pleurocladula albescens, Sauteria alpina and Apotreubia nana. Thus, deeper penetration of northern elements southward in insular part of extra-tropical East Asia noted before (Bakalin, 2010) may also be confirmed by this fact.

For five taxa, Tardoki-Yani is the southernmost locations in the world, with Blepharostoma trichophyllum var. brevirete, Lophozia savicziae and Radula prolifera known from nearest location in periglacial refugium in central Sakhalin (Bakalin et al., 2012), and Lejeunea alaskana and Plagiochila arctica, with the nearest location in Magadan Province (over $1300 \mathrm{~km}$ northward).

Summing up, the Tardoki-Yani Range hepatic flora is one of the richest local hepatic floras in the Russian Far East, counting 106 species. The flora is the mixture of temperate East Asian, boreal and arctic-alpine elements, and has no known analogues in East Asia. Many species occur here on their southern limit of distribution, and for some taxa the nearest locations are as far in the north as in the Kolyma Upland. These facts allow regard the studied flora as the largest southern refugium of arctic-alpine hepatic flora in East Asia.

\section{ACKNOWLEDGEMENTS}

I cordially thank Mr. S.A. Trofimov and Mr. A.V. Ermolenko for participation in field researches and also to the latter for providing photographs. The English in the manuscript was improved by Dr. Elena KossovichAnderson to whom I am sincerely grateful. The study was partially supported by grants from the Russian Foundation for the Basic Researches (13-04-00775, 15-3420101).

\section{LITERATURE CITED}

ANONYMOUS. 2013. National List of Species of Korea (Mosses, Liverworts). - Seoul, National Institute of Biological Resources, 161 pp. [In Korean].

BAKALIN, V.A. 2010. Distribution of bryophytes in the Russian Far East. Part. I. Hepatics. - Vladivostok, Izd-vo DVFU, $175 \mathrm{pp}$.

[BAKALIN, V.A., O.YU. PISARENKO, V.YA. CHERDANTSEVA, P.V. KRESTOV, M.S. IGNATOV \& E.A. IGNATOVA] БАКАЛИН В.А., О.Ю. ПИСАРЕНКО, В.Я. ЧЕРДАНЦЕВА, П.В. КРЕСТОВ, М.С. ИГНАТОВ, Е.А. ИГНАТОВА 2012. Bryophytes of Sakhalin. [Бриофлора Сахалина] Vladivostok, MSUN [Владивосток, МСУH], $310 \mathrm{pp}$.

[GAMBARYAN, S. K.] ГАМБАРЯН С.К. 1984. О флоре печеночных мхов высокогорий и отрогов Сихотэ-Алиня. - [On the liverwort flora of high mountains and spurs in the southern Sikhote-Alin] $B \kappa н$ : Систематико-флористическеие исследования споровых растений Дальнего Востока (отв. ред. Черданиева В.Я.) [In: Cherdantseva, V.Ya. (ed.). Sistematiko-floristicheskie issledovaniya sporovykh rastenij Dalnego Vostoka] Владивосток, ДВНЦ АН СССР [Vladivostok, Dalnevost. Nauchn. Centr Akad. Nauk SSSR]: 59-64.

GAO, C. \& T. CAO. 1983. A preliminary study on bryophytes of Changbai Mountain. - Research Forest Ecosystem: 3: 82-118.

[KHARKEVICH, S.S. \& I.B. VYSHIN] ХАРКЕВИЧ C.С., И.Б. ВЫШИН. 1984. Основные вехи становления высокогорной флоры Сихотэ-Алиня. - [The main stages of development of highland flora in Sikhote-Alin] В кн.: История растительного покрова Северной Азии (ред. Мальишев Л.И.) [In: Malyshev, L.I. (ed.). Istoriya rastitelnogo pokrova Severnoj Asii] Новосибирск, изд-во Наука, Сибирское отделение [Novosibirsk, Izd-vo Nauka Sibirskoye Otdeleniye]: 5-21.

KOPONEN, T., C. GAO, J.S. LOU \& I. JÄRVINEN. 1983. Bryophytes from Mt. Changbai, Jilin Province, Northeast China. - Annales Botanici Fennici 20: 215-232.

[KURENTSOV, A.I.] КУРЕНЦОВ А.И. 1967. Энтомофауна горных областей Дальнего Востока. - [Entomofauna of mountainous areas in Far East] M., Наука [Moscow, Nauka], 93 pp.

[PROKOPENKO, S.V.] ПРОКОПЕНКО С.В. 2011. Растения высокогорий Южного Сихотэ-Алиня (Приморский край). - [Plants of highlands of South Sikhote-Alin] Ботанический журнал [Botanicheskij Zhurnal] 96(9): 1197-1218.

[SHLOTGAUER, S.D., M.V. KRYUKOVA \& L.A. ANTONOVA] ШЛОТГАУЭР С.Д., М.В. КРЮКОВА, Л.А. АНТОНОВА. 2001. Сосудистые растения Хабаровского края и их охрана. - [Vascular plants of Khabarovsk Territory and their protection] ВладивостокХабаровск, ДВО РАН [Vladivostok-Khabarovsk, DVO RAN], 194 pp

SÖDERSTRÖM, L. 2000. Hepatics from Changbai Mountain, Jilin Province, China. - Lindbergia 25: 41-47.

[VYSHIN, I.В.] ВЫШИН И.Б. 1990. Сосудистые растения высокогорий Сихотэ-Алиня. - [Vascular plants of Sikhote-Alin Highlands] Владивосток, Дальнаука [Vladivostok, Dalnauka], 128 pp. 